\title{
Determining the quality of municipal services using SERVQUAL model
}

\author{
Nedeljko Živković \\ Quality Management and \\ Standardisation Department \\ Faculty of Organisational Sciences \\ Belgrade, Serbia \\ nedeljko.zivkovic@fon.bg.ac.rs
}

\author{
Maja Glogovac \\ Quality Management and \\ Standardisation Department \\ Faculty of Organisational Sciences \\ Belgrade, Serbia \\ maja.glogovac@fon.bg.ac.rs
}

\author{
Bojan Kovačević \\ UNOPS \\ Belgrade, Serbia \\ kovacevic.bojan@gmail.com
}

\begin{abstract}
This study deals with determining service quality of municipalities of Srebrenica, Bratunac, and Milici in Bosnia and Herzegovina. The research is conducted using a questionnaire based on SERVQUAL model which comprises two subscales, one referes to customers' expectations and another for their perception of the service quality. The model observes service quality through five quality determinants: reliability, responsibility, empathy, safety, and tangibility. The major finding obtained from data analysis, is that quality of municipal service, from the customers' point of view, is not satisfactory, that is there are significant gaps between customers' expectations and their perception of each service quality determinant, especially reliability and responsibility of service. Accordingly, the municipalities have clear notion about where to focus the improvements.
\end{abstract}

Keywords - service quality, satisfaction, SERVQUAL, municipality.

\section{INTRODUCTION}

„To achieve exceptional service, you must first listen to your customer" [1]. Quality of service can be observed as a function of the difference between customers' expectations and their perception about quality $[2,3,4]$. When it comes to determining the perception of service quality, the authors have generally adopted one of two concepts. The first is the "Nordic" perspective [4, 39], which defines dimensions of service quality using global terms such as functional and technical quality. Extension of this concept was presented by Rust and Oliver [5] proposing a three-component model: product, service delivery and service surroundings. The second, "American" perspective [6] uses terms that describe characteristics of contact with services, such as reliability, responsibility, empathy, safety and tangibility.

The perceived quality of service is based on multiple dimensions, and their assessment is considered to be a complex process which operates at the abstract level. The first conceptualizations [2, 4] were based on expectancy-disconfirmation theory from the literature on physical goods [7] which also supports the notion that quality results from comparing perceived with expected performance. Expectancydisconfirmation theory is taken as the basis of the SERVQUAL model developed by Parasuraman et al.
[2] aiming to define the method for determining the service quality using the gaps that occur between the users' expectations and their perception regarding the quality of service. While Grönroos [4] proposed two determinants, Parasuraman et al. [6] proposed five: reliability, responsibility, empathy, safety and tangibility.

A modified version of the SERVQUAL model was developed in several studies. Some of the modifications excluded completely part of the model which refers to the expectations [8]. Other modifications, on the other hand, included additional dimensions to that part of the model, such as expectations with "have to" and "need" [9], or they used alternative methods. Dabholkar et al. [10] developed a hierarchical conceptualization of service quality which include three levels: 1) the total customers' perception of service quality, 2) primary dimensions and 3) sub-dimensions. During development of their own general model of perceived service quality at three levels, Brady and Cronin [11] applied the same analytical- hierarchical perspective on the concept of service quality, criticizing the dominant conceptualization of service quality in the literature, that is SERVQUAL. They pointed out that such way of services quality observations does not give the answer to the question what exactly should be reliable, responsible, safe, empathic and tangible [11].

Various issues related to the SERVQUAL model, such as stated above, were discussed in the literature:

- The statements formulated by negation [12, 13, 14, 15];

- Dimensionality $[6,13,16]$;

- Expectations $[8,9,17,18,19]$;

- The values of the differences [20];

- Uncertainty [20, 21];

- Limitation of variance $[18,20]$;

- $\quad$ Reduced reliability [22, 23];

- Lack of construct validity $[2,18,24]$ and

- Lack of monotonicity [17, 19, 20].

Parasuraman et al. [12] presented purified SERVQUAL scale in which they paid attention to the problems wich the first version of the SERVQUAL came across with as well as to the criticism but to the lower extent. The problem of the statements formulated by negation was resolved in the version of 
the instrument in 1991. while other issues have still been discussed. Although it is conceptually meaningful, multidimensionality of the scale remains a questionable issue in methodological problems. Evidence supports a separate measurement of expectations in the light of the unique information that it carries. Finally, proofs against the value of differences were reviewed, and alternative methodologies $[12,18,19,20]$ were proposed.

However, SERVQUAL has significant advantages over other models: it defines dimensions of service quality; it recognizes the specifics of a service sector in comparison to product sector; it provides an external evaluation focused on customers; it completely covers Grönroos's model [4] but has similarities with other models; it is simple and operationalized through the scale with known psychometric features.

Despite the criticism regarding the applicability of the SERVQUAL model by some authors [21], this model may generally be considered suitable for use in the context of services [6]. Buttle [21], in his critical review of the SERVQUAL, supports the fact that this model is rapidly moving towards the institutionalization and points out that general SERVQUAL determinants should be given the leading positions in the list of attributes of a service. Regardless of the elements from the previous discussion, Boulding et al. [9] pointed out that the gap approach, which is the basis of the SERVQUAL scale, remains a common practice in the scale control. Therefore, other approaches got less attention in the literature. SERVQUAL became the best-known scale for determining quality of service in the literature and practice. On the other hand, Mokhlis et al. [25] concluded that a measurement of quality based on SERVQUAL model could be applied in the context of municipal services. Wisniewski and Donnelly [26] and Wisniewski [27] determined, in their research, quality of public services using this model. Torres [28] used the SERVQUAL model to evaluate the gap between what the service offers and what citizens expect when he was examining the role and performance of service charters and the contribution of charters to change in Spanish public administration. SERVQUAL model could also be used in banking and financial sector [29, 30]. As well, SERVQUAL model is suitable for integrating with other methods and models such as Quality Function Deployment - QFD [31, 32] or for use in decision support systems [33].

\section{THE FRAMEWORK OF THE RESEARCH}

\section{A. The aim of the research}

The aim of this paper is to determine quality of service offered by the municipalities of Srebrenica, Bratunac, and Milici, comparing expectations and perceptions of customers on different SERVQUAL determinants of service quality. This can help municipalities to identify quality determinants of the largest negative gap and to focus on them in order to identify the ways of their reduction. This analysis can also be useful for positioning the municipalities of Srebrenica region compared to municipalities of other regions for which such research was conducted.

\section{B. Research questions and hypotheses}

The problem of this research is determining quality of municipal services, so the subject of interest are dimensions of service quality from a customers' perspective that is their expectations and perceptions of the service quality. Therefore, this paper strives to answer the following questions:

Research question 1: What are customers' expectations from the quality of municipal services?

Research question 2: What are customers' perceptions of the quality of municipal services?

Research question 3: What is the gap between customers' expectations and their perceptions of the service quality?

Considering determinants of service quality from customers' point of view (reliability, responsibility, empathy, security and tangibility), based on the previous research in this context, the following hypotheses are defined:

Hypothesis 1: Customer expectations are equal for all the determinants and are at the highest level.

Hypothesis 2: The largest negative gap between customers' expectations and their perception of service quality is for determinants reliability and responsibility, while positive gaps do not exist.

\section{RESEARCH METHOD}

The instrument to be used for getting answers to the research questions was designed and tested; after that the method of data collection and the sample were determined. After the data were collected, decision on the method of their processing was made.

\section{A. Research instrument}

The questionnaire is the most common method of estimating preferences and satisfaction so, for the purpose of this research conducted in the municipalities of Srebrenica, Bratunac, and Milici, questionnaire consisting of three parts was used as a research instrument:

- general data (socio-demographic questions which include three elements: gender, age and education level determined using categorical or ordinal scales; the status of the participants in terms of being individual of an organization; experience with municipal services)

- the part related to the customer's expectations from municipal services; and

- the part related to the customer's perception of the quality of municipal services

The questionnaire was designed using the SERVQUAL model, which is characterized by simultaneous but separate data about the customer's 
expectations and perception of service quality. Both parts (the part related to the customer's expectations and the part related to the customer's perception) consist of 24 items which require responses to the seven-point scale, from „completely disagree“ (value 1) to „fully agree“ that (value 7).

Parasuraman et al. [6] suggested that the instrument should be adapted or complemented in order to fit the characteristics or specific research needs. In this research, modification of the scale is reduced to a minimum. Because the use of the SERVQUAL in local government is still in exploratory phase, the original scale was not significantly modified, except the number of questions that was increased to 24 from the original 22 questions, by adding one question to dimensions of responsibility (Staff of the municipality should allow/allows customers easy and fast access to the requested information) and one question to dimensions of security (Municipality should respect/respects the principles of confidentiality and public access to information). This conservative approach is required in order to allow comparisons to other researches that have used SERVQUAL model. However, in order to avoid ambiguity, several terms of the original instrument were replaced with the new ones, company was replaced with municipality, employees were replaced with staff of municipality, while the term customer (of service) was adopted representing the population.

Testing of the instrument was performed aiming to increase the validity of the instrument by identifying and resolving problems related to the formulation of questions in the instrument. The test provided an opportunity for finalization of the instrument and data collection method before the process of data collection started. The questionnaire was tested on a sample of 10 participants who live on the territory of one of the three municipalities. They are typical residents of the municipalities and possess a number of attributes similar to those in the survey sample. Participants did not state significant difficulties in answering the questions.

\section{B. Population and sample characteristics}

Since this research is related to attitudes of the population towards the quality of municipal services, it was necessary to put it in the appropriate municipal settings that have to meet certain requirements such as the entire range of municipal services, so that all the residents used at least one of the services; a unique institution for providing services available to all the citizens in order to avoid conflicts among different jurisdictions; homogeneous delivery of services in order to make similar level of service available to all the residents; dense, urban type of population in order to avoid distance as an obstacle for using a service; the interest of the municipal authorities. All these conditions were met by the municipalities of Srebrenica, Bratunac and Milici, with an estimated total population density of about 47000 inhabitants. It is a micro-region where UNDP Project of Regional Recovery of Srebrenica has been active for ten years.

Aiming to determine the quality of municipal services, the questionnaire was conducted on a random sample of 300 participants - users of services of the municipalities of Srebrenica, Bratunac and Milici (100 users from each of the municipality). The basic settings in this range are finite and consist only of adults (minimum 18 years old). Respondents did not have to declare themselves as voters or to prove the length of stay, as it is sometimes required in similar surveys. The sample consists of $54.8 \%$ females and $45.2 \%$ males that, according to the United Nations Development Programme [34], corresponds to the structure of the population in the observed region. When it comes to ages, the largest group of the participants are 26-45 years old people (44.9\%). Regarding the level of education, most of the respondents have high school diploma $(60 \%)$, which also corresponds to the structure of the regional population.

\section{Data analysis methods}

After data gathering, the study involved some quantitative analysis and statistical tools. SPSS (v. 17.0) was used because of its broad range of functions and relatively simple user interfaces. Used descriptive statistics mainly include the number of valid samples, mean, standard deviation, minimum and maximum of the data values. Values of gaps between customers' expectations and perception of services quality were also calculated.

\section{RESULTS}

Values of expectation dimensions (table 1) are in the range from 6.01 to 6.48 on the seven-point scale and are positioned quite close to the maximum value on the scale. The highest values are given to the Security dimension (6.4515), and the lowest values are given to the Empathy dimension (6.0160). These values, however, are not much different from the values of other dimensions.

TABLE I. DESCRIPTIVE STATISTICS FOR VALUES OF EXPECTATION DIMENSIONS

\begin{tabular}{llllll}
\hline & $\mathrm{N}$ & Min & Max & Mean & Std. Dev. \\
\hline Tangibility & 1179 & 1.00 & 7.00 & $\mathbf{6 . 1 5 7 8}$ & 1.20998 \\
\hline Reliability & 1465 & 1.00 & 7.00 & $\mathbf{6 . 4 1 4 3}$ & .99297 \\
\hline Responsibility & 1481 & 1.00 & 7.00 & $\mathbf{6 . 3 9 1 0}$ & .96515 \\
\hline Safety & 1442 & 1.00 & 7.00 & $\mathbf{6 . 4 5 1 5}$ & .94583 \\
\hline Empathy & 1438 & 1.00 & 7.00 & $\mathbf{6 . 0 1 6 0}$ & 1.24591 \\
\hline $\begin{array}{l}\text { Valid } \\
\text { (listwise) }\end{array}$ & $\mathrm{N} 1056$ & & & & \\
\hline
\end{tabular}

Values of perception dimensions (table 2) are in the range from 4.1490 (for Responsibility) to 4.5329 (for Tangibility) on the seven-point scale. There is little difference between the values of perception dimensions, but they are much smaller than the values of expectation dimensions. 
TABLE II. DESCRIPTIVE STATISTICS FOR VALUES OF PERCEPTION DIMENSIONS

\begin{tabular}{llllll}
\hline & $\mathrm{N}$ & Min & Max & Mean & Std. Dev. \\
\hline Tangibility & 1184 & 1.00 & 7.00 & $\mathbf{4 . 5 3 2 9}$ & 1.69797 \\
\hline Reliability & 1477 & 1.00 & 7.00 & $\mathbf{4 . 1 6 0 5}$ & 1.70583 \\
\hline Responsibility & 1483 & 1.00 & 7.00 & $\mathbf{4 . 1 4 9 0}$ & 1.72465 \\
\hline Safety & 1481 & 1.00 & 7.00 & $\mathbf{4 . 3 7 0 7}$ & 1.70917 \\
\hline Empathy & 1486 & 1.00 & 7.00 & $\mathbf{4 . 3 2 1 0}$ & 1.77029 \\
\hline $\begin{array}{l}\text { Valid } \\
\text { (listwise) }\end{array}$ & $\mathrm{N} 1163$ & & & & \\
\hline
\end{tabular}

Table 3 shows the values of gaps as a difference between the values of perception dimensions and expectation dimensions and serves to indicate the quality of services and hence, customers' satisfaction. If the value of perception dimension is close to the value of expectation dimension, perceived quality of the observed service dimension, as well as customers' satisfaction, is high. The largest and almost identical gaps were noticed for Responsibility dimension $(-2.2396)$ and Reliability dimension $(-2.2377)$ that may be a result of certain cultural and work habits in performing municipal services which dates from the previous period and system. The least gap was noticed for Tangibility dimension (-1.6144) pointing out relatively adequate physical surroundings of municipal facilities.

TABLE III. DESCRIPTIVE STATISTICS FOR VALUES OF GAPS BETWEEN THE DIMENSIONS

\begin{tabular}{llllll}
\hline & $\mathrm{N}$ & $\mathrm{Min}$ & $\mathrm{Max}$ & Mean & Std. Dev. \\
\hline Tangibility & 1167 & -6.00 & 5.00 & $\mathbf{- 1 . 6 1 4 4}$ & 2.14813 \\
\hline Reliability & 1447 & -6.00 & 6.00 & $\mathbf{- 2 . 2 3 7 7}$ & 2.04551 \\
\hline Responsibility & 1469 & -6.00 & 5.00 & $\mathbf{- 2 . 2 3 9 6}$ & 1.92921 \\
\hline Safety & 1428 & -6.00 & 5.00 & $\mathbf{- 2 . 0 6 2 3}$ & 1.91469 \\
\hline Empathy & 1429 & -6.00 & 6.00 & $\mathbf{- 1 . 7 0 0 5}$ & 2.08768 \\
\hline $\begin{array}{l}\text { Valid } \\
\text { listwise) }\end{array}$ & $\mathrm{N} 1028$ & & & & \\
\hline
\end{tabular}

Observing the graphical illustration of relation between customers' expectations and their perception of service quality through all 22 dimensions (figure 1), it is clear that customers have much higher expectations then what they think they really get from the services provided by the municipalities. They are satisfied with none of the dimensions of service quality. Customers' perception of services almost does not exceed the rating of 5 while their expectations of the services are pretty high and rarely drop below rating of 6 .

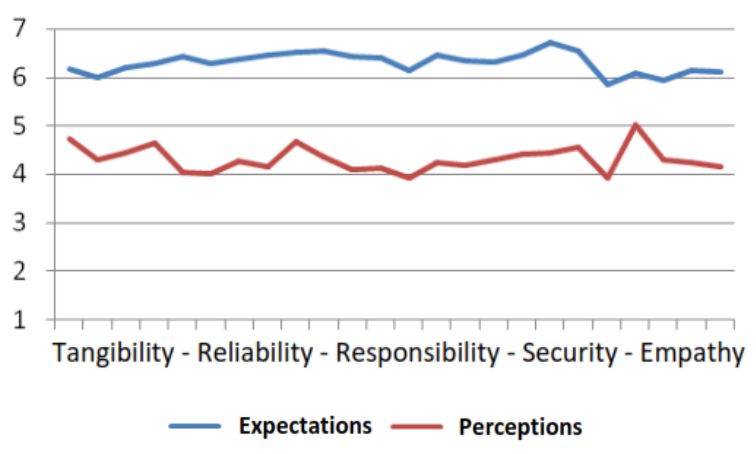

Fig.1. The relation between some customers' expectations and perception of services quality

\section{CONCLUSIONS AND DISCUSSION}

This paper deals with determining the level of citizens' perceptions of municipal services quality. The paper proposes an instrument that empirically examines attitudes towards quality as well as satisfaction with municipal services. The instrument is based on the widely used SERVQUAL scale, which serves to determine level of perceived quality of services.

The research results confirm the hypothesis 1, showing that values of expectations of all determinants are at approximately the same level, higher than 6 . This means that citizens do not have realistic expectations from municipal services. In fact, these results are consistent to some extent with the results obtained from the private sector on the same issue [35] which is confirmed in the study conducted by Parasuraman et al. [6] where the values of dimensions of expectations were in range from 5.29 to 6.47 . The results according to which residents have higher expectations from municipal services than customers from commercial services do not make much sense because customers of commercial services should be more sensitive to the cost of each commercial transaction rather than citizens, who generally prefer to limit municipal taxes and keep services at current level. When we compare obteined results with the results of the analysis of customers' satisfaction with Tesanj municipality [36] in Bosnia and Herzegovina, we notice similarity with the average value of customers' expectations of 5.9 .

From the results of the gap analysis, it can be concluded that the quality of municipal services perceived by the customers is low. This suggests that municipalities should improve their performances in all the observed dimensions of service in order to increase customers' satisfaction because they expect more than they really get from the services provided by the municipalities. As a result of this gap, it is clear that customers are satisfied with none of the dimension of service quality, and they particularly expect more from dimensions Responsibility and Reliability, which confirmes Hypothesis 2. We also see a lot of similarities between this analysis and the previously mentioned analysis of customer satisfaction with Tesanj municipality [36]. In both cases there is a significant gap between expectations and perception of 
service quality, and the largest customers' dissatisfaction is manifested for the dimensions Responsibility and Reliability, while the least difference between expectations and perceptions is noticed for the dimensions Tangibility and Empathy. Surveys conducted in the public sector in the United Kingdom, using the same method [26, 27], showed the largest differences for determinants Tangibility and Reliability. These studies also point out determinants with positive gap, which is not the case for the Municipalities of Srebrenica District.

The reason for such results can be found in various phenomena that violate relatively stable surroundings in which the municipal organizations have been located. The transfer of responsibilities from the higher to the local level has increased the complexity of relations between local government and other levels of government, private and non-profit sector, thereby expanding the range of services they provide. Some of the services that the municipalities in Bosnia and Herzegovina have recently fully assumed are nontraditional for the local government, e.g. maintenance of local roads, water supply or library services, which previously were responsibility of the higher level of government. According to the data of the Statistical Office of Republic of Srpska [37], changes in the demographic structure of the population are noted in terms that the population is getting older or still migrate to urban centres. In the cities, the fastestgrowing age group are seniors (65+), which increases demands for costly services such as transportation, social care, recreation, etc. These changes in social composition of the population have resulted in growing demands for services, not only in terms of its quantity but also in terms of increased scope and costs. More educated and sceptical citizens, increased activism manifested through determined interested parties and technological improvements, resulting in difficult to resist pressure on elected officials, also contribute to mentioned changes.

There are several reasons why this research is important for decision-makers in Municipalities. First, there is no framework for a relationship between quality of municipal services and customers' satisfaction. Better understanding what makes customers satisfied is crucially important for decisionmakers in public sector because one of the goals of customers' satisfaction research is to obtain information that will be used by municipal officials when making decisions service-related. It is worthy of clarifying this question because municipal services are related to the entire population and quality of these services has a direct influence on quality of citizens' life. Second, these trends in the public service sector began to affect the level and scope of offered services by municipalities. Identification of dimensions to which customers give priority when evaluating services may indicate the need for reduction in quality level of service that does not affect satisfaction because, according to Garvin (1987), a common mistake is introduction of quality dimensions that are not important for customers [38]. Such results can allow discrimination of improvement areas based on their impact on the customers' satisfaction. This can be useful in situations when public officials are under pressure to do more with the same or fewer resources. Third, also important for providers of municipal services, this tool can enhance their performance by adding market estimation. When evaluating achieved organizational objectives, municipal decision-makers are currently limited to internal measurement of the service. This study will provide external feedback about their productivity.

\section{REFERENCES}

[1] S. Schainker, "Commentary: To Achieve Exceptional Service, You Must First Listen to Your Customer", Public Administration Review, vol. 73(2), 2013, pp. 228-229.

[2] A. Parasuraman, V. A. Zeithaml, and L. L. Berry, "A conceptual model of service quality and its implications for future research", Journal of Marketing, vol. 49(4), 1985, pp. 41-50.

[3] G. A. Churchill, and C. Surprenant, "An investigation into the determinants of customer satisfaction", Journal of Marketing Research, vol. 19(4), 1982, pp. 491-504.

[4] C. Grönroos, "A service quality model and its marketing implications", European Journal of Marketing, vol. 18(4), 1982, pp. 36-44.

[5] R. T. Rust, and R. L. Oliver, "Service Quality: Insights and Managerial Implications from the Frontier", In R.T. Rust and R.L. Oliver (eds.) Service Quality: New Directions in Theory and Practice, Thousand Oaks, CA: Sage Publications, 1994.

[6] A. Parasuraman, V. A. Zeithaml, and L. L. Berry, "SERVQUAL: a multiple-item scale for measuring consumer perceptions of service quality", Journal of Retailing, vol. 64 (1), 1998, pp. 12-41.

[7] J. C. Olson, and P. Dover, "Effects of Expectation Creation and Disconfirmation on Belief Elements of Cognitive Structures, in Advances in Consumer Research", B. Anderson, (Ed.), vol. 3, Chicago: Association for Consumer Research, 1977, pp. 168-175.

[8] J. J. Cronin, and S. A. Taylor, "SERVPERF versus SERVQUAL: Reconciling performance-based and perceptions-minus-expectations measurement of service quality", Journal of Marketing, vol. 58(1), 1994, pp. 125131

[9] W. Boulding, A. Kalra, R. Staelin, and V.A. Zeithaml, “A dynamic process model of service quality: From expectations to behavioral intentions", Journal of Marketing Research, vol. 30(1), 1993, pp. 7-27.

[10] P. A. Dabholkar, D. I. Thorp, and J. O. Rentz, "A Measure of Service Quality for Retail Stores: Scale Development and Validation", Journal of the Academy of Marketing Science, vol. 24(1), 1996, pp. 3-16.

[11] K. M. Brady, and J. Jr Cronin, "Some new thoughts on conceptualizing perceived service quality: a hierarchical approach", The Journal of Marketing, vol. 65(3), 2001, pp. 34-49.

[12] A. Parasuraman, L. L. Berry, and V. A. Zeithaml, "Refinement and reassessment of SERVQUAL scale", Journal of Retailing, vol. 67(4), 1991, pp. 420-450.

[13] E. Babakus, and W. G. Mangold, "Adapting the "SERVQUAL" scale to health care environment: An empirical assessment", Health Services Research, vol. 26(6), 1992, pp. 767-786.

[14] T. Seay, S. Seaman, and D. Cohen, "Measuring and improving the quality of public services: a hybrid approach", Library Trends, vol. 44(3), 1996, pp. 464-490.

[15] Institute for Citizen-centered Service, 2004. How to conduct customer surveys manual. p. 29. at http://www.iccsisac.org/?s=Search, accessed October 10th, 2012. 
[16] W. P. Vogt, and R. B. Johnson, Dicnonary of statistics and methodology, Newbury Park, CA, Sage, 2011.

[17] B. Stipak, "Are there sensible ways to analyze and use subjective indicators of urban service quality?, Social Indicators Research, vol. 6(4), 1979, pp. 421-438.

[18] A. Parasuraman, L. L. Berry, and V. A. Zeithaml, "More on improving service quality measurement", Journal of Retailing, vol. 69(1), 1993, pp. 140-147.

[19] A. Parasuraman, V. A. Zeithaml, and L. L. Berry, "Reassessment of expectations as a comparison standard in measuring service quality: Implications for further research", Journal of Marketing, vol. 58(1), 1994, pp. 111-124

[20] J. R. Edwards, "The study of congruence in organizational behavior research: Critique and proposed alternative", Organizational behavior and humman decission processess, vol. 58(1), 1994, pp. 51-100.

[21] F. Buttle, "SERVQUAL: review, critique, research agenda", European Journal of Marketing, vol. 30(1), 1996, pp. 8-32.

[22] V. Prakas, and W. J. Lounsbury, "A reliability problem in the measurement of disconfirmation of expectations", in P. R. Bagozzi, and M. A. Tybout (eds.) Advances in Consumer Research (Volume 10), Ann Arbour, M. I., Association for Consumer Research, 1983, pp. 244-249.

[23] J. R. Edwards, "Alternatives to difference scores as dependent variables in the study of congruence in organizational research", Organizational Behavior and Human Decision Processes, vol. 64(3), 1995, pp. 307-324.

[24] D. T. Campbell, "Recommendations for APA tests standards regarding construct, trait, or discriminant validity", Amencan Psychologist, vol. 15(8), 1960, pp. 546-553.

[25] S. Mokhlis, Y. Aleesa, and I. Mamat, "Municipal service quality and citizen satisfaction in Southern Thailand", Journal of Public Administration and Governance, vol. 1(1), 2011, pp. 122-136.

[26] M. Wisniewski, and M. Donnelly, "Measuring service quality in the public sector: the potential for SERVQUAL", Total Quauty Management, vol. 7(4), 1996, pp. 357-365.

[27] M. Wisniewski, "Assessing customer satisfaction with local authority services using SERVQUAL", Total Quality Management, vol. 12(7-8), 2001, pp. 995- 1002.

[28] L. Torres, "Service Charters: Reshaping Trust in Government: The Case of Spain", Public Administration Review, vol. 65(6), 2005, pp. 687-699.
[29] M. Kumar, K. S. Sujit, and V. Charles, "Deriving managerial implications through SERVQUAL gap elasticity in UAE banking", International Journal of Quality and Reliability Management, vol. 35(4), 2018, pp. 940-964.

[30] U. Ramanathan, S. Win, and A. Wien, "A SERVQUAL approach to identifying the influences of service quality on leasing market segment in the German financial sector", Benchmarking: An International Journal, vol. 25(6), 2018, pp. 1935-1955.

[31] M. A. Beheshtinia, and M. F. Azad, "A fuzzy QFD approach using SERVQUAL and Kano models under budget constraint for hotel services", Total Quality Management and Business Excellence, vol. 30(7-8), 2019, pp. 808-830

[32] Z. Raziei, S. A. Torabi, S. Tabrizian, and B. Zahiri, "A Hybrid GDM-SERVQUAL-QFD Approach for Service Quality Assessment in Hospitals", Engineering Management Journal, vol. 30(3), 2018, pp. 179-190.

[33] A. Maghsoodia, A. Saghaeia, and A. Hafezalkotob, "Service quality measurement model integrating an extended SERVQUAL model and a hybrid decision support system" European Research on Management and Business Economics, In Press - Available online 29 May 2019.

[34] United Nations Development Programme, Srebrenica Regional Development Programme. PRODOC, p. 6, 2009.

[35] L. L. Berry, A. Parasuraman, and V. A. Zeithaml, "Improving service quality in America: Lessons learned", Academy of Management Executive, vol. 8(2), 1994, pp. 32-52.

[36] Analysis of customer satisfaction with services of Municipality Tesanj, 2009, p. 16 , at http://www.opcinatesanj.ba/admin/slike/doc/Analiza\%20zado voljstva\%20korisnika\%20usluga\%20za\%20internet.pdf, accessed November 10th, 2012.

[37] Statistical Office of the Republic of Srpska. Statistical Yearbook of the Republic of Srpska. Graph of population changes, p. 87, 2011.

[38] D. A. Garvin, "Competing on the eight dimensions of quality", Harvard Business Review, vol. 65(6), 1997, pp. 101109

[39] A. Ancarani, "Supplier evaluation in local public services: Application of a model of value for customer", Journal of Purchasing and Supply m anagement, vol. 15(1), 2009, pp. 33-42 